\title{
Improving Sales in SME Using Internet Marketing
}

\author{
M. Zainal Arifin, Ahmad Fahmi, Didik D.P, Heru WH, M. Ashar P \\ ${ }^{I}$ (Electrical Engineering Department, State University of Malang, Indonesia)
}

\begin{abstract}
In Indonesia, SMEs are the backbone of the Indonesian economy. Number of SMEs until 2011 to reach around 52 million. SMEs in Indonesia is very important for the economy because it accounts for $60 \%$ of GDP and $97 \%$ of the workforce holds. But access is limited to financial institutions only $25 \%$ or 13 million SMEs who have access to financial institutions. Indonesian government, SMEs, through the Department of Cooperatives and SMEs, in each province or regency / city.

Although Small and Medium Enterprises (SMEs) is driving the nation's economy, but in reality many of the problems SMEs are still entangled. The main thing to note is the ability of SMEs to access a wider market. Because of the ability to change and adapt to a changing environment will determine the existence of small businesses in the nation's economy. In the end, the existence of small businesses that have high competitiveness will strengthen the nation's economy as a whole. Thus, in this study will use an appropriate technology tools that can provide assistance in introducing products through internet and increase sales in each SME

This study uses a sample of students at the State University of Malang that can make a significant contribution in the small and medium businesses that are being initiated by students.
\end{abstract}

Keywords: Small Medium Enterprise, Internet Marketing, Sales Improvement

\section{INTRODUCTION}

Small and Medium Enterprises SMEs abbreviated is a term that refers to a type of small business that has a net worth of more than Rp 200 million, excluding land and buildings. And stand-alone business. According to the Presidential Decree no. 991998 Small Business sense is: "The economic activities of the people are small-scale business sectors that constitute the majority of small business and need to be protected to prevent unfair competition."

Small business criteria according to Law no. 9 of 1995 is as follows:

1. Has a net worth of at most Rp. 200.000.000, - (Two Hundred Million) excluding land and buildings

2. Has annual sales of Rp. 1.000.000.000, - (One Billion Rupiah)

3. Owned by Indonesian citizen

4. Standing alone, is not a subsidiary or branch company which is not owned, controlled by, or affiliated directly or indirectly with Medium or Large Business Enterprises

5. Shaped the efforts of individuals, business entities are not incorporated, or incorporated entity, including cooperatives.

How do I start a business that his notabe in rural areas but there is no capital for existing businesses just the spirit to move forward to create jobs in the village to reducing the unemployment rate in the village / town and does not have to wander into town.

There are the problems faced by small and medium enterprises. The role of small businesses in Indonesia is recognized as very important in the national economy, especially in aspects such as increased employment, income distribution, rural economic development and an increase in non-oil exports. Had been a lot of work done by the government to assist the development of small businesses through a variety of program development or small business development program including the partnership between medium and large businesses to small businesses.

However, small business development to date is running very slow. For example, in manuaktur industry sectors, the level of productivity or output contribution of small and cottage industries to the formation of total value added in the sector or the gross domestic product is still relatively low compared with medium and large industries.

One cause of the lack of success of the development or small business development in Indonesia in improving the condition or performance of the group of small businesses, from position to position weak and strong traditional and modern is the pressure of the government's policy orientation program or more located in the "social" than " economics and business ". So far, efforts to develop small-scale economic activities are generally labor-intensive and carried out by the poor less educated shown to increase or reduce the number of their opinions unemployment and inequality. 
The fundamental problem in the field of management for small entrepreneurs in various sectors are:

Capital

1. Bank lending rates are still high, and loans can be expensive

2. Information sources of financing of non-bank financial institutions, such as state income allowance funds and venture models, is still lacking. This information includes information sumbe types of financing as well as the requirements and filing procedures.

3. Systems and procedures for bank credit from financial institutions and non-banking complex and long, in addition to credit disbursement waiting time is uncertain.

4. Less banking standards inform the credit proposal, so that small businesses can not afford to make a proposal in accordance with banking criteria.

5. Banks do not understand the criteria for assessing the eligibility of small businesses in small business, so the number of loans approved often do not fit the needs of small businesses.

\section{Marketing}

1. Bargaining power in dealing with small entrepreneurs great entrepreneurs always weak, especially relating to the pricing and pwmbayaran system, as well as the layout and small business products in department stores and supermarkets.

2. Employers or professional associations have a role in coordinating the unhealthy competition among similar businesses.

3. Information to market products at home and abroad are still lacking, for example about the desired product, who is the buyer, the place of purchase or potential markets, product markets as well as procedures for tendering work primarily on business services.

\section{Raw Materials}

1. Inadequate supply of raw materials and fluctuations, among others, the export and import policy changes, large buyers who control the raw material, the reluctance of the employers to make a contract with small businesses

2. Raw material prices are still too high and fluctuate due to monopolistic market structure or market controlled by employers.

3. Quality raw material is low, partly because of the lack of standardization and manipulation of raw material quality.

4. System cash purchase of raw materials complicate small entrepreneurs, while payments are generally not cash sales.

\section{Technology}

1. Skilled labor is hard earned and maintained, partly because of lack of education and training institutions to produce skilled manpower according to the needs of small businesses.

2. And access to information technology resources are lacking and uneven, while still kkurang vigorous dissemination efforts.

3. Equipment specifications to suit the needs (appropriate technology) difficult to obtain.

4. No independent agency and not play, especially institutions that examines the technology offered by the market to pngusaha small, so that this technology can not be utilized optimally.

5. The role of government agencies, non-government and universities to identify, locate, distribute and perform the technical development of new technology or appropriate technology for small businesses is less intensive.

\section{Management}

1. Management patterns that suit your needs and stage of business development ditmukan difficult, partly because the knowledge and managerial skills small business is relatively low. As a result, small businesses have not been able to put together the right business strategy.

2. Separation between corporate financial management and family or household has not been done, so that small businesses have difficulty in controlling or manage cash flow, as well as in the planning and financial reporting.

\section{Bureaucracy}

1. Licensing is not transparent, expensive, complicated, discriminatory, long and uncertain, as well as the vertical overlap (between the center of the area) and horizontal (inter-county agencies). 
2. Enforcement and implementation of laws and various regulations are still lacking, and tend to be less assertive.

3. Small entrepreneurs and small business associations are less involved in the formulation of policies on small business.

4. Levy or surcharge in the administration of capital gains allowance funds SOE profits and other capital sources are quite high.

5. Export quota allocation mechanism does not support busaha small to be able to export its products.

6. Many charges are often not accompanied by adequate services.

\section{Infrastructure}

1. Electricity, water and telephone cost is expensive and often faced harassment officer in addition to poor service.

2. Lack of adequate infrastructure such as roads, electricity, telephone, water, and waste handling facilities and disruption.

\section{Partnership}

1. Partnership between small and medium-sized and large enterprises in the marketing and payment systems, both products and raw materials, have not felt useful.

2. Partnerships between small businesses to medium and large enterprises in technology transfer is still lacking.

In this research will be conducted increasing sales by using internet technology and web marketing advertisement on SMEs.

\section{Marketing}

\section{LITERATURE REVIEW}

Marketing is the process of developing an integrated communication which aims to provide information about the goods or services in relation to satisfying the needs and desires of humans.

Marketing begins with the fulfillment of human needs which later grew into the human desire. For example, a human being needs water to meet the needs of thirst. If there is a glass of water the thirst needs will be met. But humans do not just want to meet their needs but also wants to fulfill his wish is for example a glass of clean water brand Aqua and easy to carry. The man then chose Aqua bottles as required in accordance with the thirst and desire are also easy to carry.

Process in the fulfillment of human needs and desires that is the concept marketing.Konsep it was four components in marketing comprises the $4 \mathrm{P}$ :

1. Product (product)

2. Price (price)

3. Place (place, including distribution)

4. Promotion (promotion

Because marketing is not an exact science such as finance, marketing mix theory also continues to grow. In the process, well known 7P where 3P term is hereinafter People (People), Physical Evidence (Physical Evidence), Process (Process). Author Seth Godin, for instance, also offers a new theory, namely P Purple Cow.

Marketing is seen as more art than science, then a marketing expert depends on the skills of more consideration in making policy-oriented rather than certain knowledge.

Economists view to marketing is to create a time, a place where the product is necessary or desirable and delivered the product to satisfy the needs and desires of consumers (the marketing concept). Someone who works in marketing so-called marketers. The marketer should have knowledge in the concepts and principles of marketing so that marketing activities can be achieved in accordance with the needs and desires of humans, especially the intended consumer.

According to Kotler and Keller: Marketing is an organizational function and a set of processes for creating, communicating, and delivering value to customers and for managing customer relationships in ways that benefit the organization and its stakeholders (An organizational function and a set of processes for creating, communicating and deliver value to consumers and build / manage relationships with companies and consumers to benefit stakeholder) 
While Marketing Management: Marketing management is the art and science of choosing the target markets and getting, keeping, and growing customers through creating, delivering, and communicating superior customer value (the art and science of choosing target markets and getting, keeping and developing consumer and communicate the value of -value for the customer). So, the most important in marketing (marketing) is how we should be able to deliver value / value of a product that we sell to the consumer so that the consumer will be able to feel the the benefits of the products we sell.

Sales figures are not important? Important whether or not a sales figure in the marketing depends on the orientation / marketing concepts used by the company itself.

Kotler and Keller divided into four types:

a. Product Concept

The belief that consumers will choose products with the best values of In terms of price quality and other aspects related to the product.

b. Production Concept

Company that would be interested in buying consumer goods can be obtained easily and at low prices.

c. Selling Concept

The concept of selling. With this concept will become more and more sell to be very good value.

d. Marketing concept

This concept emphasizes the right product to the consumer appropriate.

Three concepts above is a concept used in the era of the 40s to the 80 s era with an emphasis on sales figures that can be achieved by a company. The success of the marketing process is determined by sales figures can be achieved by the company. While the Concept Marketing is a marketing approach that gives priority to products / services that are appropriate for the customer. Because the concept is the fulfillment of customer satisfaction when using the product or service is more important than the quantity of products or services that can be achieved by the company. With the fulfillment of the desired consumer satisfaction, is expected to be able to make consumers become loyal to a product or service that we provide, especially satisfied customers will do the word of mouth promotion by itself.

However sales figures remain a crucial thing because sales figures to be a benchmark in terms of quantity whether we succeed or not the product in the market, but still being a most important thing is that consumers feel comfortable with the value of the products we sell

\section{e-Marketing}

In the world of non-traditional marketing, we often find some of the terms are confusing and often overlapping. Therefore, in this article I tried to explain what it is e-Marketing and the difference with the Internet-Marketing. e-Marketing or electronic-Marketing is any part of the e-Business that utilizes electronic medium to perform marketing activities in order to achieve marketing objectives. There are various forms of emarketing, internet-marketing, interactive and mobile-marketing-Marketing. e-Business e-Business can be defined as the utilization of electronic media in everyday business activities. There are several levels in the use of electronic medium, for example, there are companies that sebenuhnya rely on electronic medium, while other companies only use for certain tasks.

\section{The difference between e-Business, e-Commerce and e-Marketing}

e-Business is a very broad unity involves a complex system that utilizes electronic medium to perform or assist certain business activities. the most appropriate e-Commerce is defined in the context of the transaction. For example, the electronic transaction of money, information or entertainment in the category of eCommerce. Technically, e-commerce is part of e-Business. Such as already described above, e-Marketing is part of the e-Business that involves electronic medium to achieve marketing goals. e-Marketing is at the strategic level as a complement to traditional marketing and business strategy. In addition there is one more term that is interactive-marketing, and in general can be interpreted as part of the e-Marketing which involves a level of interaction.

\section{Advantages of e-Marketing}

There are several advantages of e-marketing in comparison with traditional marketing:

a. Reduction in costs through automation and use of electronic media

b. Cebat responsiveness for end users and for Marketers

c. The ability to measure and the data pemgumpulan

d. Personalize

e. Allow for interaction

f. The downside of e-Marketing 
In addition to the above advantages, e-Marketing also has some disadvantages:

a. Reliance on technology

b. Security and privacy issues

c. The cost of maintenance because the technology continues to evolve

d. Uneven access to technology, especially in Indonesia

e. Increased price transparency resulting price competition

f. Global competition

In addition, based on existing survey beberpa obstacle for companies to implement e-Marketing, including: the lack of ability to measure the impact of e-marketing programs, limited internal capacity to run and difficult to convince senior managers.

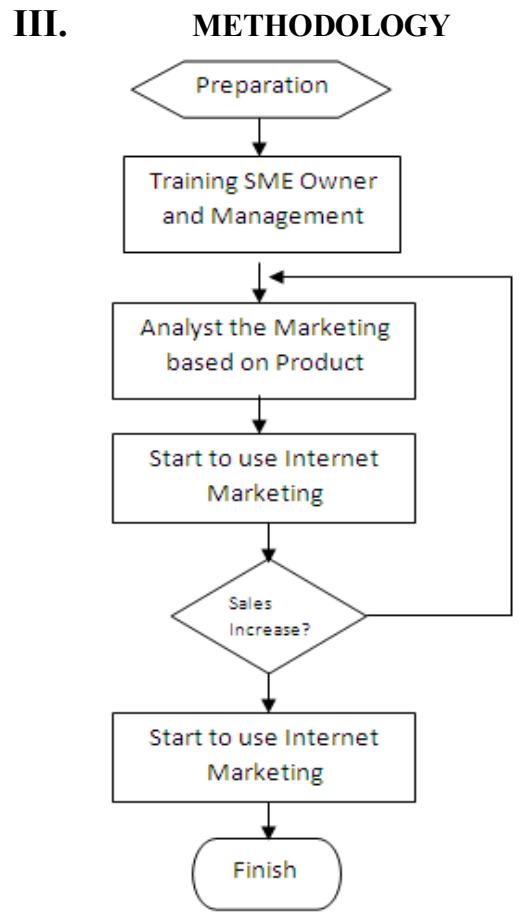

This research consist of several step that will be listed and describe in the flowchart diagram below :

The preparation make sure that all of research requirement already covered. Analyst is to make the first conclusion according to the several product and conducted by the research and the owner of SME's. After that starting to using internet as a marketing tool based on social media or personal website.

\section{RESULT}

Results of this study found that there was a significant increase in sales of some products, especially products applications and media that has been widely downloaded. As part of the marketing tricks, we have created several products to be free to download but the service is limited to the product brand name companies can improve SMEs by $76 \%$.

\section{CONCLUSION}

Multicultural marketing experts. All facets of business today is trying to find a way to connect with consumers. But there are some companies that failed to attract minority customers. Many companies fail in a relationship with minorities, because they do not want to take the time to get to know more closely with consumers. It is good practice to start developing website that can help SME's owner promote their product. the result is more good than conventional method, it can increase sales by $76 \%$.

\section{REFERENCES}

[1] Bailey, Matt, Internet Marketing: An Hour a Day (Sybex, 2011)

[2] Chaffe, Dave, Internet Marketing: Strategy, Implementation and Practice (4th Edition), (Prentice Hall, 2009)

[3] Hodell, Chunk, SMEs From the Ground Up (ASTD-Press, 2013). 